Relations industrielles

Industrial Relations

\title{
Gindin, Sam, Canadian Auto Workers: The Birth and Transformation of a Union
}

\section{Pradeep Kumar}

Volume 51, numéro 3, 1996

URI : https://id.erudit.org/iderudit/051121ar

DOI : https://doi.org/10.7202/051121ar

Aller au sommaire du numéro

Éditeur(s)

Département des relations industrielles de l'Université Laval

ISSN

0034-379X (imprimé)

1703-8138 (numérique)

Découvrir la revue

Citer ce compte rendu

Kumar, P. (1996). Compte rendu de [Gindin, Sam, Canadian Auto Workers: The Birth and Transformation of a Union]. Relations industrielles / Industrial Relations, 51(3), 594-597. https://doi.org/10.7202/051121ar

Tous droits réservés @ Département des relations industrielles de l'Université Laval, 1996
Ce document est protégé par la loi sur le droit d'auteur. L’utilisation des services d’Érudit (y compris la reproduction) est assujettie à sa politique d'utilisation que vous pouvez consulter en ligne.

https://apropos.erudit.org/fr/usagers/politique-dutilisation/ 
interesting alternative model of managerial styles that is worth further study.

The book lacks an integrating final chapter. Such a chapter would draw comparisons among the countries, point out similarities and differences, and reduce the wealth of practical information to a smaller number of useful theoretical distinctions.

A theoretical problem in this work is that conflict is treated as an undifferentiated construct. There are many different kinds of conflict in organizations: among individual employees, between superiors and subordinates, among departments competing for scarce organizational resources, among groups of employees (perhaps on ethnic or racial lines), between union and management.
Some tighter conceptualizing would help here: different conflict venues likely involve different conflict management procedures. Another problem was pointed out to me by a research assistant who looked over the book - just how valid are the generalizations? Can one really generalize the conflict management techniques of an entire country's business force? What about inter-firm differences, particularly between very large and fairly small companies?

In all, this book is an easy read, but of more use to practitioners than theorists. Oh well, half a loaf... but it's a very good half-loaf indeed!

JOHN KERVIN

University of Toronto

\section{Canadian Auto Workers: The Birth and Transformation of a Union}

by Sam GINDIN, Toronto, Ontario, Lorimer \& Company Ltd Publishers, 1995, $\mathrm{x}, 291$ p., ISBN 1-55028-499-1(bound) and ISBN 1-55028-498-3(pbk).

The Canadian Auto Workers (CAW), the largest private sector union in Canada, has a long and rich history. It also has a mystique in the North American labour movement because of its deep rooted culture of ideological resistance and political activism. The union prides itself on its spirit of independence, innovative bargaining, a tradition of internal democracy and organizational dynamism, and a dedication to social unionism philosophy - a form of "unionism which is rooted in the workplace but understands the importance of participating in, and influencing, the general direction of society." Since its birth in the late 1930s as the Canadian district of the International Union of Automobile Workers of America (UAW) it has bargained hard for better wages and working conditions, and struggled vigorously for stronger legislative protections for workers and a universal social safety net as a "right of citizenship." The union is credited with pioneering a number of collective agreement provisions which have become a stand- ard feature of unionized employment in Canada. Key among these are union security, deferred annual wage increases and a cost of living clause in multi year agreements, paid vacation and holidays, employer financed supplementary unemployment benefits and other income security programs. It broke away from its parent, the UAW, in 1985 and became an independent national union when its leadership concluded that the UAW was losing its ability to act as a social movement and had ceased to be an independent voice of labour by accepting concession bargaining as a "new direction" to help auto employers become competitive. Since the split the CAW has become even more confident of its ability to pursue its distinct path of workplace reforms and social and political change. The exuberance is related to the union's continuing impressive gains at both the collective bargaining table and in the political arena as well as its phenomenal growth over the past ten years due to a series of mergers and aggressive 
organizing. Mergers in particular have radically changed the union, transforming it from an auto workers union, representing largely male workers in a selected few large workplaces in Central Canada, into a general union representing workers in a diverse range of industries spread across the country. While the diversification has strengthened the union encouraging "the development of a broader working class consciousness" and leading to a greater rank and file activism and a much higher level of servicing, a number of controversial mergers and the union's excessively ideological approach to electoral politics has created deep divisions between the CAW and other private sector unions. The union, therefore, has become both a source of inspiration and fragmentation of the Canadian labour movement.

Sam Gindin's book is a valuable contribution towards a better understanding of the mystique of the CAW. As the director of research and an assistant to the President for over twenty years he has been involved in building the union and helping to shape its history. $\mathrm{He}$ is also a noted labour scholar, a frequent contributor to many labour publications. The book therefore combines the benefits of active participation and involvement and an intimate knowledge of the issues with the scholarly detachment associated with academic and policy research. As he notes in the preface, "this book is not a history of the CAW, but a personal essay on that history," his reflections on the past, present, and the future of the union. The book, written to mark the 10th anniversary of the union and its transformation in a short span of time, provides a unique insider's perspective on the culture of the union, its successes and failures, internal and external challenges facing the union and the Canadian labour movement, and the future prospects and priorities of the union. Among the major themes covered in the book are the role of the left in the early development of industrial unionism in
Canada and within the Canadian district of the UAW, similarities and differences between the culture of the UAW and the $\mathrm{CAW}$, the reasons for the split in the union in 1985 leading to the formation of the CAW, the diversification of the union since 1985 following the mergers and its potential consequences. In addition to providing an understanding of the history, the book also looks at the future outlining the key issues and challenges facing the union and the Canadian labour movement in the current environment of uncertainty. The author, through the book, hopes to stimulate discussion and debate within the CAW and outside on the critical challenges confronting labour in the 1990s.

The book is divided into four parts. Part One (chapters 1-2) covers the developments in the 1920 s and the early 1930 s and the "challenge of developing a new kind of unionism to give voice to the workers in the emerging mass production industries." Part Two (chapters 3-5) discusses events of the next two decades, leading to the establishment of the UAW in Canada, struggles for recognition, growth and consolidation of the union, structural changes and the innovative gains at the collective bargaining table, and the development of social unionism and ties with the CCF/NDP. Part Three (chapters $6-7$ ) provides reflections on the problems of the sixties, the growing tensions within the union on workplace issues, emerging nationalism in Canada, increasing marginalization of labour in the U.S., and the beginning of the concessions bargaining era. Part Four (chapters 8-10) deals with the events leading to the historic split in 1985 and its aftermath, transformation of the union through mergers, the current problems and issues facing the union and the priorities for the future to create what the author calls "movement unionism," "a more powerful version of social unionism" which existed in the early days of the union. Movement unionism, according to the author, means "making 
the union into a vehicle through which its members can not only address their bargaining demands but actively lead the fight for everything that affects working people in their communities and the country."

A key argument of the author is that while ties with American labour have been important in the development of industrial unionism in Canada, providing significant benefits, and in the early days the inspiration to overcome uncertainties and fears, the Canadian union culture has been distinct based on different aspirations and approaches to working class solidarity as well as distinct political culture and institutions. These differences have played a crucial role in shaping the history of the CAW, including the union's split from the UAW. As Gindin explains:

The differences that had emerged between the American and Canadian UAW were rooted in a combination of factors: economically, in the delayed growth of Canada's manufacturing base; politically, in the later development of supportive labour legislation and the consequent longer struggles for union recognition; internally, in the persistence of a strong left based in strong locals; structurally, in the uniqueness of the Canadian Council; and culturally, in the differing role of nationalism in the two countries (p. 278).

These factors, he believes "affected the union's spirit in Canada... The union culture reflected Canadian culture, but in quite a distinct way, linked as it was to the experiences of the working class and this particular union" (p. 133).

Gindin maintains that the split, the "move to independence," was indicative of new confidence and maturity within the union in Canada. It was not easy since the Canadian district had long been dependent on its parent organization for leadership and support. The split, therefore, "was a statement about coming of age that contrasted with the country's own increasing dependence on the United
States... one step in the building of the working class." The independence was further reinforced by subsequent mergers which "nationalized the union by involving all regions of Canada and no longer limiting unionization to Central Canada."

National differences are not the only reason behind the distinct CAW culture, according to Gindin. The CAW also differs from the UAW in political and bargaining strategies and notions of the role of unions in a global economy. It strongly adheres to an adversarial system of industrial relations and has developed a clear agenda and strategy for workplace changes. On the political front the union has rejected the electoral politics of the NDP in favour of building closer alliances with social and community groups. It has a different view of international labour solidarity to challenge the "the logic of globalization." Gindin believes that "progressive internationalism can only be built on a strong and progressive nationalism." He maintains that:

If labour wants to challenge the internationalism of the corporations, it must be first strong nationally... national strength means more than allegedly strong unions. Unions that are strong enough to sell wage concessions and false partnerships will reinforce rather than challenge the view that there are no alternatives.

Rather, national strength requires local and national institutions - unions, community organizations, political parties, and the service and administrative bodies within the various levels of state - that are accessible to working people, and that are democratic and effective. These institutions must be able to articulate working class needs and fight on behalf of and alongside workers in their struggles. Only on such a basis can internationalism be meaningfully achieved (p. 204).

Gindin realizes that the CAW culture of resistance and change could not continue indefinitely. The union has become 
increasingly vulnerable due to intensified corporate pressures for workplace change, growing public policy trend towards weakening worker and union rights including an attack on established social safety programs, divisions within the labour movement, and the "crisis in social democracy" as a result of the uneasy relationship between labour and the NDP. Gindin is short on specifics on how to meet the challenges facing the CAW or the broader labour movement. He emphasizes, quite rightly, the need to further democratize the union by promoting inclusiveness, activism, and rank and file participation in all spheres of union life. He also suggests broadening the orientation of the union to "movement unionism" or community unionism that existed in the 1920s and the early 1930s, "opening the way for unions to become, as far as possible the centres of working class life and culture." However, he offers very few insights into strategies to accomplish this new unionism. I was also disappointed in the lack of any reference to "organizing the unorganized" - the key challenge facing the CAW and the Canadian labour movement. The neglect is especially unfortunate in light of the serious downsizing in sectors where unions have been traditionally strong, the growing employment in service industries where unions have been unable to make any inroads, and the poor organizing performance of the CAW in recent years. Similarly, Gindin has little to say about how to heal the divisions within the $\mathrm{Ca}$ nadian labour movement. This is particularly surprising in view of his emphasis on building the "national base" as a prerequisite to international labour solidarity to effectively respond to the corporate agenda of globalization and competitiveness. In the same vein, while he states that "[the] example and profile of the CAW challenged the direction of other private sector unions, and left many of their leaders uncomfortable" he provides no analysis of how, and to what extent, the CAW experience with the UAW and with the auto industry employers is relevant to other unions. Are there any lessons that can be drawn from this experience? Some unions would argue that Canadian autonomy is no longer a general issue with most international unions in Canada, and the CAW experience with the Big Three is beyond compare due to the unique nature of the Canadian auto industry being a part of the highly integrated continent-wide North American production system that encompasses Canada, Mexico and the United States.

Overall, this is a very readable and an extremely informative and stimulating book on the history and culture of one of the most powerful and highly controversial union in Canada. It provides a fascinating account of the CAW from its origin to the present, as well as important insights into labour history and contemporary industrial relations issues. The book is a valuable supplement to Bob White's autobiographical account of his association with the CAW, Hard Bargains: My Life on the Line, published in 1987.

PRADEEP KUMAR Queen's University

\section{Perspectives occidentales du droit international des droits économiques de la personne \\ par Lucie LAMARCHE, Bruxelles, Éditions de l'Université de Bruxelles et Édi- tions Bruylant, 1995, 513 p., ISBN 2-8004-1106-6 (éd. U. de Bruxelles), 2-80270967- 4 (Bruylant).}

Les droits économiques de la personne, notamment le droit au travail, au logement, à un niveau de vie suffisant, droits de la personne de la deuxième génération, après les droits politiques classiques, s'attachent à différentes sources sur le plan international : construit de l'Organisation internationale du travail, dès 